\title{
Student Expectations and Quality of Postgraduate Education: The Case for Public Universities in Uganda
}

\author{
Dr. Victoria Tamale Kaggwa \\ College of Education and External Studies (CEES) \\ Makerere University, Kampala, Uganda \\ Dr. Denis Sekiwu \\ Faculty of Science \& Education \\ Busitema University, Tororo, Uganda \\ Dr. Esther Frances Naluwemba \\ Faculty of Education \\ Kyambogo University, Kampala, Uganda
}

\begin{abstract}
In order to chant John Stuart Mill's Utility Theory in Service Delivery, this study focuses on the quality of student support in Postgraduate Education at Makerere University's College of Education and External Studies (CEES). Using 50 Masters' and Doctoral Student respondents, the study investigated an alleged gap between students' expectations and experiences of service quality in Postgraduate programs offered by the College. Four dimensions play a cardinal role in the measurement of student support service quality in postgraduate education, namely supervision support, infrastructure, administrative support, and academic facilitation. The 4-dimensions are student dissatisfiers necessitating interventions to improve quality. From the StepWise Regression computations, support supervision and administrative support are the most important determinants of quality postgraduate support. As recommendations, support supervision and administrative support must be targeted as drivers of quality student support at this level. The Utilitarian Theory, if wellintegrated, provides moral bounds in which quality support systems could be optimally scaled up.
\end{abstract}

Keywords: Postgraduate Supervision, Academic Service Quality, Postgraduate Education, Total Quality Management, Quality Assurance in Universities, Student Support Services

\section{INTRODUCTION}

The issue of quality service delivery is a Utilitarian characteristic which this study tries to address. In the Utility satisfaction hypothesis, humans in every society aim at ensuring moral uprightness - what Plato calls the "Summum Bonum" (Schofield, 2006). Within utilitarian rumination, moral uprightness would denote man's highest pursuit for quality and excellence, which John Stuart Mill's Utilitarianism refers to as "happiness or pleasure" (Ryan, 1990; Donner, 1991). Utility satisfaction is therefore a yardstick for moral evaluation and moral direction that expands into a measure or standard of moral value (Long, 1990). Something of moral value must have human expectations at the forefront, and quality delivery is one of such expectations (Sultan \& Wong, 2010). The underlying interpretation here is that the pursuit for quality is one of the forms of utility satisfaction.

In this study, we argue that the pursuit for education quality is a utility maximizing factor. It is a central apparatus that cultivates society which should be suitably managed so that it conveys 
the desired results (Nsubuga, 2008). The need for managing education applies to all levels (from kindergarten to university) and all modes of education (formal, informal, non-formal). Education managers are accountable for managing not only the academic aspect of teaching and learning but also every indispensable facet that makes students' learning a pleasurable and prolific experience. This is the contribution of education in developing a whole person experience and in producing graduates that meet the current market needs of any country (Clewes, 2003:74; Ogunleye, 2013:49). But one of the most essential aspects which education managers should deem crucial is quality. For example, the quality of teaching and learning, the quality of educational materials and the quality of the student support services that are supplied. In the abyss of postgraduate education, quality is arguably a vital trade for education providers (Backhouse, 2009; Boote \& Beile, 2005; Commonwealth Department of Science and Training, 2002). The intention of centring on quality is to perk up the international credence obtaining to a Higher Degree Qualification and to augment original thinking, at this level, as means to securing societal development (McAlpine \& Norton, 2006).

Quality is contextually bound. Whatever can be regarded as quality in one milieu may not be germane in another (Evans, Brian \& Oladeji, 2011:164; Maila \& Pitsoe, 2012:8). Therefore, a compelling and context-responsive apparatus is required to exclusively gauge student support service quality, and for managers, to spot areas of the educational practice that require contemplation. After political independence from Britain, Uganda entered an era of rapid social and economic development, in which human capacity building became one of the priorities of government (Ssekamwa, 2002). When the National Resistance Movement (NRM) government came into power in 1986, its cardinal agenda was promoting quality human capital as a precursor to economic growth and development of the country (Government White Paper, 1993; Nsubuga, 2008). In this venture, the government, among other things, has set its sights on the construction of opportunities for its citizens to develop skills relevant in a hastily changing economy (Rwendeire, 2012). This also applied to the higher education sector that is considered to generate and contribute to transfer of knowledge, and to develop skilled human power that, in turn, has a stake in reducing poverty and bringing about socioeconomic development (Kasozi, 2002; Muyingo, 2004).

To deal with the soaring graduate unemployment in recent times, it is imperative to ensure quality higher education provision. This could encompass underscoring the quality of student service provision in universities to ensure the creation of innovative and creative products for the labour market (Rwendeire, 2012). This implies that the quest to respond to the knowledge economy is partly to augment the possibilities for advanced level learning and research production, which also calls for the expansion of postgraduate training through service quality provision (Kiley \&Wisker, 2009).

Thus postgraduate education is a key driver of the national economy 'since graduates with this level are deemed capable of infusing management logistical systems, developing critical thinking, are mooted to be key developers of innovation and development, are able to alter existing conceptual directions, and allowing for new possibilities'(Academy of Science of Southern Africa-ASSAf, 2010:79). Additionally, the debate about liberalization of higher education consequently has called for increased university education. From a single public university (Makerere University) way back in 1990, today we have over 50 universities in the country and many more are still coming up (Mugagga, 2010; Kasozi, 2002). In the economic sensibility of this, the market of university education in Uganda today defines a perfectly competitive market of education. Because of the many suppliers of university education, higher education has become a competitive commodity determined by the forces of demand and supply. In the words of French Economist Jean-Baptiste Say (1767-1832), we can argue that 
"supply creates its own demand" which is popularly referred to as Say's Law of Markets (Truett \& Truett, 1990). This means that if the products from universities to the labour market or society are poor, the demand for university education will decline tremendously. Therefore it is central that the quality of university education products, especially for postgraduate education, is scaled up to make its products more competitive at the labour market (Kasozi, 2002; Rwendeire, 2012).

As the value of postgraduate education amplifies, trends are underway to hasten intellectual mobility (Connell, 2007) as well as stretching those intercultural experiences that define diverse research supervision leaderships (Cadman \& Ha, 2001). This intellectual exodus manifested in postgraduate training, however, calls for numerous epistemic and axiological inquiries regarding students' expectations of the quality of service and supervision obtaining.

\section{PROBLEM STATEMENT}

The problematic case for this study is that, intermittently, there are several aspects of this study that have not been investigated before and which merit scientific post-mortem, and two issues stand out perfectly-the students' perception of the quality of postgraduate support services offered, and how postgraduate education service quality can be measured. With reference to the College of Education and External Studies (CEES), Makerere University, we scientifically delved into these unexplored empirical realities-seeking answers to these subsequent research questions:

a) What are students' expectations of the quality of postgraduate support services offered?

b) What is the Extent or Level of students' actual experiences of the support services they received?

c) Is there a gap (difference) between students' expectations and actual experiences of the quality of postgraduate support services provided?

d) To what extent does the quality of postgraduate student support service quality influence Students' satisfaction levels?

Before addressing the afore-mentioned research questions, we sought a definition of "Quality Student Service Delivery" (the dependent variable) from a critical appraisal of the literature. From an own definition of "Quality Student Service Delivery", we distilled latent constructs which guided instrument development in the methodology.

\section{LITERATURE REVIEW \\ Conceptual Literature Review: Meaning and Nature of Quality Service Delivery in Postgraduate Education}

Literature review, for this part, is majorly premised on the study variable "Quality Student Service in Postgraduate Education. The intent is to provide an inclusive understanding of the emerging latent constructs or measurements of this variable for instrumentation purposes. We methodically asked ourselves these decisive questions "What is quality? How is quality viewed in the higher education sector? What are the dimensions of service quality? How is service quality measured?"

With regard to the meaning of the term "quality", there are varied scholarly conceptions of the maiden term. The term "quality" changes from time to time (Harvey \& Green, 1993:10). However, it is the receiving customers who judge quality of services that they receive (Sandmaung \& Khang, 2013:262). Much as quality is understood to be a slippery and elusive concept which cannot be easily defined (Mwenje \& Saruchera, 2013:142), it remains something that is "value-laden" for the user of a product or service (Juran, 1999:2.2). Quality, thus, is the basis for economic success, improved product or service, as well as customer satisfaction and 
competitiveness (Talib, Rahman \& Qureshi, 2013). Harvey and Green (1993), however, state five ways of thinking about quality: "quality can be viewed as exception, as perfection, as fitness for purpose, as value for money, and as transformative" (p.11).

We elaborated the deeper meaning of each of the five ways of thinking about quality. First, the inherent meaning of quality as an exception is that it is special. This specialty implies that the product or service is distinctive and not accessible to everyone, but only to elites. This gives quality a sense of "excellence of products/services" and setting standards in that regard (Harvey \& Green, 1993:11-12; Mhlanga, 2010:15). Therefore, quality postgraduate education must encompass an array of excellence in terms of the services given and the product released on the labour market in order to attract world class status (National Council for Higher Education's Quality Assurance Framework, 2012). Second, quality as perfection is expressed in terms of conformance to a pre-determined specification and has no defects every time it is checked (Ndudzo, 2014:40).

Third, quality is viewed as fitness for purpose whereby the functionality of the product or service is the main concern. According to this view, if a product or service serves the purpose that it is designed for, then it has met the definition of quality "Effectiveness" (Harvey \& Green, 1993:16; Mhlanga, 2010:15). In Uganda's higher education sector, quality is measured by three functions or aims of higher education: quality of teaching, research, and community service. These demystify an institution's competitiveness and effectiveness in the global web-metric rankings. The fourth definition of quality labels quality as "value for money", which is related to an organization's financing of product or service providers, demanding effectiveness and efficiency for the cost that they have incurred as a "return on investment" (Mhlanga, 2010:16). With quality provision, the product or service must enhance customer satisfaction to gain a larger market share (Juran, 1999). The last definition of quality is quality as transformationseen in terms of bringing about a "qualitative change" in the consumer which has the effect of enhancing and empowering the consumer (Harvey \& Green, 1993:24-25). For in an era of mass higher education, value-added transformation ought to become the central element of any concept of quality.

We also sought to analytically understand theoretical precincts of Service Quality within the higher education Sector. We therefore asked the question "How do these definitions of quality apply to the higher education context?" Studies on service quality in the higher education context are relatively scanty. In existing literature, studies on post-graduate students are even scantier (Barnes, 2007:317). Examples of studies that have concentrated on service quality among post-graduate students are indicated in the proceeding paragraphs. For example, there is Lampley (2001) who concentrated on doctoral students in six state-supported universities in the US. Pereda (2006) focused on overseas postgraduate students enrolled in a university in the UK; Barnes (2007) who engaged Chinese post-graduate students enrolled in one business university in the UK; and Sultan and Wong (2013) who completed an exploratory study among both undergraduate and post-graduate students in one university in Australia. In all these above studies, student satisfaction is the major ingredient influencing the existing students to stay in the same institution, to re-enroll in the future, and to attract new ones to join that specific institution, and to ensure that the institution secures its competitive edge.

Students' complaints, on the other hand, are mostly caused by dissatisfaction with the services rendered by the relevant higher education institutions (Jancey \& Burns, 2013:311; Watson, 2003:148). Tan and Kek (2004:17) also hold the opinion that quality is evaluated by taking student satisfaction, which translates into meeting students' needs and expectations, into account. Universities must make it a priority to secure students' satisfaction so that more and 
more students can be attracted and more funding can be secured (Sultan \& Wong, 2010:260). Specifically for postgraduate students, it is argued that whether or not students complete their studies or discontinue in the middle is determined by how much they are satisfied. For example, Dann (2008:339) states that when research students do not get the expected service from their supervisors, they tend to drop out. Similarly, the major cause for postgraduate students' satisfaction is the quality of educational services they receive from the higher education institution they are enrolled at (Bolliger \& Halupa, 2012:82). This is why Evans et al (2011:165) conclude "satisfaction will result in motivation and increase the effectiveness of the organizational members, leading to high quality services to the customers (learners), parents, and employers". Therefore, the issue of quality should be prioritized by paying attention to the context of the education-receiver whereby quality education must be locally relevant and culturally appropriate.

The higher education sector is influenced by various stakeholders, which may include government(s) that finance the sector, students that are enrolled in the system and who pay fees, senior management and staff members of the higher education institutions, employers who require quality graduates to recruit from, and the society at large (Muyingo, 2004). All of these stakeholders demand quality graduates from higher education institutions because the social and economic growth that is envisioned in every country comes as a result of welltrained personnel from these institutions (Jung, Wong, Li, Baigaltugs \& Belawati, 2011:64). This, in turn, creates a competitive atmosphere in the higher education environment which results in higher education institutions continually working harder to be able to secure a competitive edge.

In the higher education context, education can undoubtedly be regarded as a service (Hill, 1995:11). Even Joseph, Yakhou and Stone (2005:68) state that "higher education possesses the characteristics of a service industry. Educational services are intangible, heterogeneous, inseparable from the person delivering it, variable, perishable, and the customer (student) participates in the process". The main purpose and outcome of education is not awarding educational certificates (though educational institutions do so to signify that the student is their graduate). According to Ong and Nankervis (2012:279), the main purpose of education is the development of knowledge. Knowledge in turn is abstract as it is found in the minds of students and teachers and hence no one can take ownership of it. Consequently, education can be categorized as a service rather than a product or something tangible. This is explained as follows: "the higher education sector can be considered a market place and university education a marketable service".

Postgraduate Education systems, like all other systems of higher education, are marked by processes of assuring the quality of their offerings. Therefore, postgraduate Education awarding institutions continuously strive to provide the best quality education and student support services possible; the latter of which is the foundation of the students' and the institution's success (Teeroovengadum, Kamalanabhan, \& Seebaluck, 2016). There are different views on how quality is assessed in Postgraduate Education, whereby the principles of quality assessment that apply in conventional education must be directly applied to assessment of the quality of postgraduate Education. On the other hand, it is argued that the openness, originality in thinking, flexibility and continuous employment of technology that make up the distinctive nature of the postgraduate programme, constitute important criteria for evaluating its quality (Mulu Nega, 2012).

However there is another viewpoint which suggests that "higher education is not about delivering specifications ... it is, arguably, about encouraging ... the analytic and critical 
development of the student" (Harvey \& Green, 1993:16). Perfection in quality postgraduate services is relevant in education in order to develop excellent human knowledge, ensure proper planning of student support service provision (Mhlanga, 2010:15) in order to meet students' needs and expectations (Ndudzo, 2014:41). Quality as transformation in the higher education context also implies that students are assisted to become more and more independent and self-confident as they progress in the system, referred to as crossing the conceptual threshold. Mulu Nega (2012: 29-30) writes that quality in the learning environment focuses on the enhancement paradigm of changing behaviors among learners, through transformation of the life experiences of students", in terms of transforming their specific levels of knowledge, skills and abilities throughout their higher education interactions.

Pertaining to the dimensions and measurements in service quality, the current trend suggests that human services play a more important role in economic development apart from the economic acquisition of goods (Cronin \& Taylor, 1992:55; Malhotra, Ulgado, Agarwal, Shainesh $\& \mathrm{Wu}, 2005: 257)$. Service-providing institutions therefore focus on service quality and how to improve it. Institutions that wish to succeed and be sustainable must pay much attention to ensuring service quality (Zeithaml, Berry \& Parasuraman, 1996:31). This, however, starts with an understanding of the meaning of, and variables that characterize "service quality". On this accord, Nyenya and Bukaliya (2015:45) have defined service quality as an approach to manage business processes in order to ensure full satisfaction of the customer to increase competitiveness and effectiveness of the industry. The two core ideas contained in this above definition, according to Pereda (2006:27), are that service-providing firms should focus on satisfying their customers' needs and on gaining a competitive advantage over their competitors. Further still, Ong and Nankervis (2012:278) define services as "any act or performance that one partly can offer to another that is essentially intangible". This definition focuses on services being intangible. Similarly, Parasuraman, Zeithaml and Berry (1985:42) regard intangibility, heterogeneity and inseparability to be the three most important factors that define services. These factors make service quality an abstract construct different from products or goods.

Intangibility refers to acts or actions that are difficult to measure or verify. Heterogeneity points to the inconsistent nature of services from one firm to another and from one customer to the other whereas inseparability constitutes the interaction between the staff providing the service and the customer. In a discussion on the meanings of quality, the literature provides a fourth factor, namely perishability. Thus these four above factors, (intangibility, heterogeneity, inseparability, perishability), distinguish services from goods (Lovelock \& Gummesson, 2004:21).

Service quality features vary from one context to another which, in turn, presupposes the dimensions varying from one kind of service to the other (Parasuraman, Zeithaml \& Berry, 1994:114; Teeroovengadum, et al., 2016:246) and also varying across cultures and economies (Malhotra et al., 2005:260). The American model of Parasuraman et al. (1985:46) comprises ten dimensions (or categories) which they labeled as "service quality determinants". These are tangibles, reliability, responsiveness, communication, credibility, security, competence, courtesy, understanding or knowing the customer, and access. From the outset, these authors were aware that these dimensions have overlapping characteristics and must be subjected to empirical research for further refinement. In their study, Parasuraman, Zeithaml, and Berry (1988:17) employed a rigorous purification process, which involved the generation of items, collection of data from selected service-firm users (done twice at different locations), and employment of statistical procedures like Cronbach's alpha and factor analysis. After all these actions have been taken, they were able to formulate five dimensions (three original and two 
combined) consisting of 22 measuring items. These dimensions are tangibles (appearance of physical materials and front-line staff members), reliability (accuracy and dependability in service provision), responsiveness (willingness in assisting customers and provision of prompt service), assurance (winning customer trust through knowledgeable and skilful service provision and courteousness), and empathy (being caring to each customer by giving individual attention) (Teeroovengadum, et al., 2016:246).

Other examples of the dimensions of service quality include three major dimensions which are physical quality, corporate quality and interactive quality (Hasan \& Kerr, 2003:287). Then Li and Kaye (1999:146) suggested five dimensions, namely corporate image, internal organization, physical support of the service, staff/consumer interaction, and the degree of customer satisfaction. Finally, Jayasundara (2009) also indicates that service quality is measured through fifteen items that can be clustered into three dimensions, namely hygiene, enhancing and dual-threshold dimensions. Still in higher education context, support services should include those services that are different from classroom experience, like the library and other physical facilities (Yeo \& Li, 2014:114). Similarly, Barnes (2007:324) added "university" and "guidance" dimensions in addition to the five dimensions of SERVQUAL. Moreover, the curriculum, the academic facilities and the teaching methodology are important aspects to consider as dimensions.

A further study by Pereda, Airey and Bennett (2007) adopted the three dimensions of studying service quality among post-graduate overseas students in UK. In their study, the 'recognition' dimension, which is the corporate quality of the university as perceived by the students, accounted for $34 \%$ of the variance in explaining the dependent variable. They concluded that "provision of services is not only about the actual facilities ... it also highlights the fact that ... they [students] judge their institution". According to Yener (2013:52) "university image can be defined as the sum of all the beliefs an individual has towards the university". Such an image increases (or decreases) the brand of the university in the country and among students who in turn recommend (or fail to recommend) the university to prospective students.

From extensive conceptions borne from volumes of literature, we logically retreated to define "Quality Service Delivery in Postgraduate Education" as guaranteeing student satisfaction by providing student support needs and expectations in order to ensure competitiveness in postgraduate education. Thus several scales bringing out the latent constructs of this definition (i.e. student needs, expectations, and competitiveness) were analytically appraised (in the methodology) in order to develop an instrument for gathering empirical data for the study.

\section{Theoretical Literature Review: The Gaps Model}

The theoretical framework enabled us advance an analytical framework for the study-the pattern of data analysis was pertinently developed from the Gaps Model. The Gaps Model (Figure 1), by Parasuraman, Zeithaml and Berry (1985), was psychometrically constructed from the SERVQUAL instrument (Parasuraman, et al., 1988:23), and it emphasizes the difference between perceptions and expectations of customers as well as the level of service quality (Parasuraman, 1985:43). The Gaps Model is built on five gaps.

Gap 1 is named the "customer expectation vs. management perception gap" referring to the discrepancy between how executives of companies perceive the expectations of their customers and the actual expectations of customers who make use of those services. The executives may not always recognize the features and performance levels which customers use to judge a service to have fulfilled the desired quality (Parasuraman, et al., 1985:44). This gap is influenced by marketing research orientation; upward communication and level of 
management (Parasuraman, et al., 1994:339) determining the size of this gap becoming larger if the information managers receive about their customers is scanty. Gap 2 of this model is called the "management perception of service quality specification" gap. It concentrates on the discrepancy between how executives of companies perceive customers' expectations and how accurately these perceptions are translated into specifications of service quality (Parasuraman, et al., 1985:45; Parasuraman, et al., 1994:339).

Gap 3, the "service quality specifications vs. service delivery gap," is the gap between how service quality should be provided (as determined by executives) and how service is delivered in practice (Parasuraman, et al., 1985:45). Front-line staff members are the face of the company and represent the company in the eyes of customers. However, the service delivery cannot be strictly standardized (though companies usually have guidelines for doing so) as human beings differ in their personalities, and in the ways they interact with customers, which result in variations in the manner front-line staff members perform the delivery of services. This gap is also influenced by factors such as teamwork for a common goal among employees, matching of skills of staff members with their jobs, the technologies used in service delivery, staff members' ability to control their jobs with flexibility, the way employees' working behavior is evaluated, employees' level of role conflict in satisfying customers' needs, and role ambiguity as perceived by employees in understanding what they are expected by their managers to do.

Gap 4 refers to the "service delivery vs. external communications gap" referring to either the existence or absence of external communication about services to customers. If the company, for example, advertises itself widely but delivers less than what it promises, then it creates a service quality gap (Parasuraman, et al., 1985:46). 


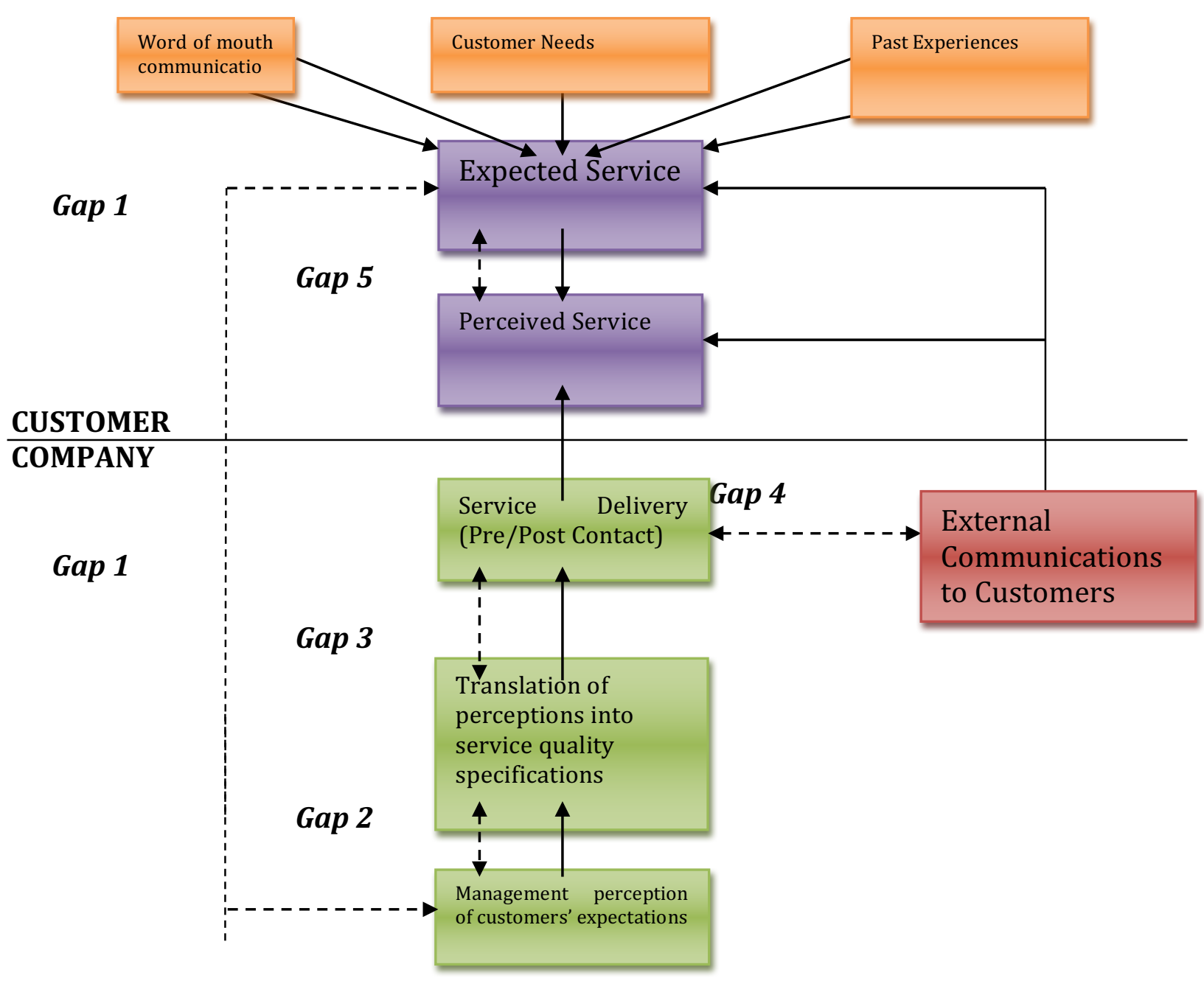

Fig.1: The Gaps Model of Service Quality; Source: (Parasuraman et al., 1985:44)

Basically, Gap 4 is influenced by two important aspects: the interaction and communication of different sections of the company in serving customers, and the promise the company makes to customers in the effort of gaining more market share and establishing competitive advantage. The latter aspect could result in a mismatch between what is promised and what is delivered. Hence, more interaction and communication is needed between different departments of the company in meeting its strategic objectives.

Finally Gap 5, the "expected service vs. perceived service gap," is a gap that primarily refers to customers. This gap of service quality was originally established from the focus-group discussions that were held with customers of the four companies mentioned above. It is the gap that exists between what customers expect to get from a certain service and how they perceive the delivered service: does the service correspond with their expectations? Has it frustrated, simply met or exceeded their expectations? Service quality is guaranteed when services meet or exceed customers' expectations. Service quality is related to the direction and the magnitude of the differences between what customers expect and what they perceive to have received in the service encounter (Zeithaml, et al., 1996). Gap 5 is the most important gap for the purposes of this study because it investigates the difference that exists between students' expectations of student support services and their actual experiences of the same, which is the centric problematic for this study. 


\section{RESEARCH METHODS}

For the research design, this study adopted the Context-Specific Case-Study (Creswell, 2009) where a single case-Postgraduate Students-was studied in depth as located in a specific context-the College of Education and External Studies (CEES) Makerere University. The sample characteristics specified were postgraduate students mainly to provide their expectations and actual experiences of the quality of support services they receive from CEES and Makerere University. For example, Grönross' Nordic model identified that perceived service quality is dependent on the customer (in this case the student) in terms of technical quality which is what the customer gets, functional quality which is about how the customer gets the service, and image which is the brand of the service on offer to the customer (Hasan \& Kerr, 2003:287). This study therefore concentrated mainly on student views, as the unit of analysis, to judge the quality of support services they receive in support of their postgraduate education as customers.

Using a sample of 50 student respondents, we computed their socio-demographic characteristics. The age range of the majority of the respondents was between 31-50 years (43.8\%). With gender composition, (40) $80 \%$ were males and only (10) $20 \%$ were female respondents. On marital status, $30(60 \%)$ of the respondents were married and (20) 40\% single. Most student respondents belonged to the Master of Education Management and Planning course $20(40 \%)$ and the Masters in Educational Administration 15 (30\%) with few doctoral students 5 (10\%). The rest of the students $10(20 \%)$ comprised of other Masters courses at CEES.

During the phase of instrument development, the researcher reviewed previously developed scales-those that were in line with the latent constructs developed in the literature review section (Section 3). A Conditional Relations Guide (CRG) explicating previously developed scales on service quality is presented in Table 1. In service quality literature, one of the most influential instruments is the SERVQUAL scale, which has 22 items that are grouped into five dimensions. These items measure both expectations and experiences of service quality (Parasuraman, et al., 1985). As a result of the rigorous steps the authors went through in developing SERVQUAL, this instrument satisfies all the psychometric requirements of an instrument of its nature (Dann, 2008:336).

Most importantly, SERVQUAL has the advantage of providing a balanced view of service quality (by comparing expectations and perceptions). Consequently, it is "more objective and less erratic" than most other similar scales (Yeo, 2009:65). SERVQUAL is known for its strong diagnostic power (Tan \& Kek, 2010:23) that assists to identify the major problem areas that need improvement in the services provided, and also to which areas resources should be channeled by the service firms for increased effectiveness (Kitchroen, 2004:17). The SERVQUAL addresses "the whole-person experience" of students (Sultan \& Wong, 2013:77). Services in the higher education sector are not limited to classroom experiences which are expressed in terms of tangibles like availability of course materials or assignment feedback. Apart from the SERVQUAL, the other previously developed scales included the HEdPERF (Firadus, 2005), DL-sQUAL (Shaik, Lowe \& Pinegar, 2006) (See Table 1). These sources are internationally recognized and widely used to measure quality of support service in postgraduate education. 
Table 1: Meta-Analysis of Service Quality Dimensions in Higher Education Institutions

\begin{tabular}{|c|c|c|c|c|}
\hline AUTHOR AND YEAR & PURPOSE & DIMENSIONS OF SERVICE QUALITY & $\begin{array}{l}\text { NUMBER OF } \\
\text { ITEMS }\end{array}$ & CONTEXT \\
\hline Lampley, 2001 & $\begin{array}{l}\text { To identify gaps } \\
\text { between } \\
\text { expectations and } \\
\text { experiences, and } \\
\text { determine level of } \\
\text { satisfaction } \\
\text { Seven }\end{array}$ & $\begin{aligned} & \text { Seven dimensions: } \\
& \text { - } \text { Responsiveness/caring } \\
& \text { - } \text { University services } \\
& \text { - } \text { Accessibility/safety } \\
& \text { - } \text { Knowledge/scheduling } \\
& \text { - } \text { Facilities/equipment } \\
& \text { - } \text { Public relations } \\
&\end{aligned}$ & $\begin{array}{l}25 \text { items that } \\
\text { measure } \\
\text { expectations and } \\
\text { experiences, and } \\
\text { satisfaction }\end{array}$ & $\begin{array}{l}\text { Doctoral students } \\
\text { enrolled in six } \\
\text { state universities } \\
\text { in USA }\end{array}$ \\
\hline Pereda, 2006 & $\begin{array}{l}\text { To identify service } \\
\text { quality measures } \\
\text { and their impact } \\
\text { on satisfaction }\end{array}$ & $\begin{array}{cl}\text { Four dimensions: } \\
\text { - } & \text { Recognition } \\
\text { - } & \text { Quality of instructions and } \\
& \text { interaction with faculty } \\
\text { - } & \text { Sufficiency of resources } \\
\text { - } & \text { Quality of facilities } \\
\end{array}$ & $\begin{array}{l}18 \text { items that } \\
\text { measure students' } \\
\text { experiences and } \\
\text { their satisfaction }\end{array}$ & $\begin{array}{l}\text { Overseas master's } \\
\text { students enrolled } \\
\text { at one university } \\
\text { in UK }\end{array}$ \\
\hline Firadus, 2005 & $\begin{array}{l}\text { To come up with } \\
\text { an instrument } \\
\text { named HEdPERF } \\
\text { by comparing its } \\
\text { efficacy with } \\
\text { SERVPERF }\end{array}$ & $\begin{aligned} & \text { Six dimensions: } \\
& \text { - } \text { Non-academic aspects } \\
& \text { - } \text { Academic aspects } \\
& \text { - } \text { Reputation } \\
& \text { - } \text { Access } \\
& \text { - } \text { Program issues } \\
& \text { - } \text { Understanding }\end{aligned}$ & $\begin{array}{l}41 \text { items that } \\
\text { measure service } \\
\text { performance }\end{array}$ & $\begin{array}{l}\text { Students in six } \\
\text { higher learning } \\
\text { institutions based } \\
\text { in Malaysia }\end{array}$ \\
\hline Shaik, et al., 2006 & $\begin{array}{l}\text { To design an } \\
\text { instrument named } \\
\text { DL-sQUAL }\end{array}$ & $\begin{array}{l}\text { Three dimensions: } \\
\text { - Instructional service quality } \\
\text { - } \quad \text { Management and } \\
\text { administrative services } \\
\text { - Communication }\end{array}$ & $\begin{array}{l}23 \text { items that } \\
\text { measure online } \\
\text { distance learning } \\
\text { services }\end{array}$ & $\begin{array}{l}\text { Undergraduate } \\
\text { and postgraduate } \\
\text { students in a } \\
\text { distance learning } \\
\text { institution located } \\
\text { in South-east } \\
\text { region of USA } \\
\end{array}$ \\
\hline $\begin{array}{l}\text { Sarrico, Ferreira, and } \\
\text { Silva, } 2013\end{array}$ & POLQUAL & $\begin{aligned} & \text { Six dimensions: } \\
& \text { - } \text { Empathy } \\
& \text { - } \text { Assurance } \\
& \text { - } \text { Rangibles } \\
& \text { - } \text { Responsiveness } \\
& \text { - } \text { Promptitity } \\
&\end{aligned}$ & & $\begin{array}{l}\text { Persons who use } \\
\text { the service of } \\
\text { Portuguese } \\
\text { National Police }\end{array}$ \\
\hline $\begin{array}{l}\text { Teeroovengadum, et } \\
\text { al., } 2016\end{array}$ & $\begin{array}{l}\text { To design an } \\
\text { instrument named } \\
\text { HESQUAL }\end{array}$ & $\begin{array}{l}\text { Five dimensions with nine sub- } \\
\text { dimensions: } \\
\text { - Administrative quality } \\
\circ \quad \text { Attitude and behaviour } \\
\text { - } \quad \text { Support facilities quality } \\
\text { - Code educational quality } \\
\circ \quad \text { Curriculum } \\
\circ \quad \text { Attitude and behaviour } \\
\circ \quad \text { Competence } \\
\circ \quad \text { Pedagogy } \\
\text { Transformative quality } \\
\text { - Physical environment quality } \\
\circ \quad \text { Support infrastructure } \\
\circ \quad \text { Learning setting } \\
\circ \quad \text { General infrastructure }\end{array}$ & $\begin{array}{l}48 \text { items that } \\
\text { measure service } \\
\text { performance }\end{array}$ & $\begin{array}{l}\text { Students in the } \\
\text { University of } \\
\text { Mauritius }\end{array}$ \\
\hline
\end{tabular}

\section{Source: Literature Review}

As a result, a total of 32 items of service provision to postgraduate students were selected from the instruments identified in literature review (See Table 1). These items are those that also had the potential to measure students' expectations and experiences of service quality. These items were given to ten (10) staff members of Makerere University and of CEES to appraise them. These ten evaluators recommended the exclusion of four of the items because of redundancy and perceived irrelevancy of the items in measuring service quality.

We computed parametric tests to validate and ensure reliability for the original 32-item instrument (which had originally 5-dimensions-Support Supervision, Infrastructure, Administrative Support, Academic Facilitation, and Corporate image) that we selected from items in Table 1 which were deduced from literature review. We used Cronbach's alpha coefficient to test reliability of the instrument and all dimensions had a Cronbach's alpha result greater than 0.7, which was well above the acceptable level. The overall Cronbach's alpha of 
the 28-items instrument meant to measure Student Support Service Quality was 0.878 (88\%), which implied an instrument with a strong reliability coefficient. Our final 28-item instrument had 4-dimensions such as "support supervision" with 10-items, "infrastructure" with 8-items, "administrative Support" with 6-items, and "academic facilitation" with 4-items. The dimension "corporate image" was later dropped using factor analysis. A 5-point Likert Scale denoted by $1=$ Strong Disagree up to 5=Strongly Agree, was used.

After cleaning and editing the data, it was quantitatively analyzed using descriptive statistics (Mean, Standard Deviation, percentages, Minimum and Maximum) mainly to describe students' expectations and the level of actual experiences of the quality of postgraduate support services offered in Makerere University in general and at the College of Education and External Studies (CEES) in particular. The paired t-test was used to establish whether there was a gap (difference) between students' expectations and their actual experiences of the support services quality. Finally, multiple regression analysis was used to compute the extent to which postgraduate student support service quality influences students' satisfaction levels. A Statistical Package for Social Scientists (SPSS) was used to do the analysis, and below are the study findings.

\section{STUDY FINDINGS \\ Students' expectations of the quality of postgraduate support services}

The quality of postgraduate education and training depends partly on availability of quality student support services (Parasuraman, et al., 1994:114; Teeroovengadum, et al., 2016:246). It was therefore imperative for us to describe the kind of student expectations from the institution as far as attaining quality postgraduate education is concerned. We asked the research question, "What are students' expectations of the quality of postgraduate support services offered in Makerere University in general and at CEES in particular?" A total of 28 items measured students' expectations and experiences of support service quality in postgraduate education. When analyzing students' expectations, descriptive statistics of the measures of centrality (means and standard deviations) along with their range values (minimum and maximum) were used to describe the extent of the students' expectations for each of the four dimensions considered separately (See Table 2).

In Table 2, all mean values indicated high students' expectations on the four dimensions of support service quality (Mean values were above 3.0) and they had similar responses to this effect (Standard deviations for all dimensions were below 1.0). To begin with, students at the College of Education and External Studies (CEES), for example, had very high expectations for support supervision (grand $\mu=3.45 ; 86 \%$ ) to give timely responses to students' submissions $(\mu=3.58)$ on the higher side and to give information on research funding possibilities (Min $\mu=3.12$ ) on the lower side because funding is often hard to get. Secondly, students' expectations are high on availability of infrastructure (grand $\mu=3.47 ; 87 \%$ ) like online material collections in the library $(\mu=3.58)$ and reasonable access to computer laboratories $(\mu=3.29)$. 
Table 2: Students' Expectations of Postgraduate Support Service quality at Makerere and CEES

\begin{tabular}{|c|c|c|c|c|c|}
\hline DIMENSIONS & ITEMS & Min & Max & Mean & Std. Dev \\
\hline \multirow{10}{*}{ SUPERVISION SUPPORT } & Clear comments from supervisors & 1.00 & 4.00 & 3.54 & 0.61 \\
\hline & Supervisors acknowledge receipt of students' submissions & 1.00 & 4.00 & 3.48 & 0.74 \\
\hline & Information on ethical clearance procedures & 1.00 & 4.00 & 3.43 & 0.78 \\
\hline & Alerting students on useful resources & 1.00 & 4.00 & 3.43 & 0.76 \\
\hline & Using different technological media for communication & 1.00 & 4.00 & 3.41 & 0.73 \\
\hline & Guidance on governing rules and policies & 1.00 & 4.00 & 3.48 & 0.71 \\
\hline & Supervisors' timely responses to students' submissions & 1.00 & 4.00 & 3.58 & 0.72 \\
\hline & Supervisors' periodically encouraging their students & 1.00 & 4.00 & 3.46 & 0.74 \\
\hline & Comments of supervisors being fairly consistent over time & 1.00 & 4.00 & 3.50 & 0.67 \\
\hline & Supervisors' giving information on research fund possibilities & 1.00 & 4.00 & 3.12 & 1.01 \\
\hline \multicolumn{4}{|c|}{ Grand Totals (Supervision Support) } & 3.45 & 0.53 \\
\hline \multirow{8}{*}{ INFRASTRUCTURE } & Online materials collection in the library & 1.00 & 4.00 & 3.58 & 0.72 \\
\hline & Accessibility of online library throughout the year & 1.00 & 4.00 & 3.49 & 0.79 \\
\hline & Up-to-date ICT resources & 1.00 & 4.00 & 3.53 & 0.69 \\
\hline & Assistance for ICT-related challenges & 1.00 & 4.00 & 3.40 & 0.78 \\
\hline & Main and College library stocking subject-relating materials & 1.00 & 4.00 & 3.56 & 0.70 \\
\hline & Main and College library stocking recent research books & 1.00 & 4.00 & 3.53 & 0.73 \\
\hline & Accessibility of computer labs & 1.00 & 4.00 & 3.29 & 0.94 \\
\hline & Accessibility to Other libraries like MISR, departmental libraries & 1.00 & 4.00 & 3.32 & 0.95 \\
\hline \multicolumn{4}{|c|}{ Grand Totals (Infrastructure) } & 3.47 & 0.62 \\
\hline \multirow{6}{*}{$\begin{array}{l}\text { ADMINISTRATIVE } \\
\text { SUPPORT }\end{array}$} & User-friendliness of the CEES e-mail & 1.00 & 4.00 & 3.61 & 0.63 \\
\hline & Provision of information on postgraduate application & 1.00 & 4.00 & 3.59 & 0.63 \\
\hline & Responses on admission decisions & 1.00 & 4.00 & 3.55 & 0.69 \\
\hline & User-friendliness of registration and re-registration & 1.00 & 4.00 & 3.55 & 0.68 \\
\hline & Time span in communicating HDC decisions on proposal & 1.00 & 4.00 & 3.51 & 0.73 \\
\hline & Provision of information on administrative procedures & 1.00 & 4.00 & 3.45 & 0.74 \\
\hline \multicolumn{4}{|c|}{ Grand Total (Administrative Support) } & 3.56 & 0.62 \\
\hline \multirow{4}{*}{$\begin{array}{l}\text { ACADEMIC } \\
\text { FACILITATION }\end{array}$} & Doctoral proposal development training & 0.00 & 4.00 & 3.64 & 0.62 \\
\hline & Relevance of training to students' research & 0.00 & 4.00 & 3.62 & 0.62 \\
\hline & Provision of programs for post-proposal students & 0.00 & 4.00 & 3.48 & 0.70 \\
\hline & Training on data analysis soft-wares & 0.00 & 4.00 & 3.53 & 0.68 \\
\hline \multicolumn{2}{|c|}{ Grand Total (Academic Facilitation) } & & & 3.57 & 0.54 \\
\hline
\end{tabular}

Administrative support is also a necessary prerequisite (grand $\mu=3.56 ; 88 \%$ ) to provide rules of procedure for quality assurance in postgraduate education such as registration regulations $(\mu=3.55)$, responses on postgraduate admissions $(\mu=3.55)$, and application requirements $(\mu=3.45)$. Finally, academic facilitation is also key (grand $\mu=3.57 ; 89 \%)$ to ensuring quality student support service where research proposal development trainings (Max $\mu=3.64$ ), data analysis training $(\mu=3.53)$ and few post-proposal programs (Min $\mu=3.48$ ) like conference presentations to disseminate research data become pertinent. Apart from the above student expectations of support service quality in postgraduate education, actual student experiences were also computed as indicated in section 4.2 below.

\section{Students' Actual Experiences of Postgraduate Support Services}

In this section, we discuss the extent or level of students' actual experiences of the postgraduate support services they received from Makerere University in general and CEES in particular. To do this, we ask the question, "What is the Extent or Level of students' actual experiences of the support services they received from the University in general and CEES in particular?" and data presented (Table 3). The expected range of each of the items was between 0 (none) and 4 (very much). 
Table 3: Students' actual experiences of support service

\begin{tabular}{|c|c|c|c|c|c|}
\hline DIMENSIONS & ITEM & Min & Max & Mean & $\begin{array}{l}\text { Std. } \\
\text { Dev }\end{array}$ \\
\hline \multirow{10}{*}{ SUPPORT SUPERVISION } & Clear comments from supervisors & 0.00 & 4.00 & 2.82 & 1.01 \\
\hline & Supervisors acknowledge receipt of students' submissions & 0.00 & 4.00 & 2.84 & 1.02 \\
\hline & Information on ethical clearance procedures & 0.00 & 4.00 & 2.44 & 1.14 \\
\hline & Alerting students on useful resources & 0.00 & 4.00 & 2.35 & 1.19 \\
\hline & Using different technological media for communication & 0.00 & 4.00 & 2.51 & 1.06 \\
\hline & Guidance on governing rules and policies & 0.00 & 4.00 & 2.65 & 1.05 \\
\hline & Supervisors' timely responses to students' submissions & 0.00 & 4.00 & 2.68 & 1.07 \\
\hline & Supervisors' periodically encouraging their students & 0.00 & 4.00 & 2.56 & 1.12 \\
\hline & Comments of supervisors being fairly consistent over time & 0.00 & 4.00 & 2.71 & 1.00 \\
\hline & Supervisors' giving information on research fund possibilities & 0.00 & 4.00 & 1.67 & 1.38 \\
\hline \multicolumn{2}{|c|}{ Grand Total (Support Supervision) } & & & 2.54 & 0.83 \\
\hline \multirow{7}{*}{ INFRASTRUCTURE } & $\begin{array}{l}\text { Online materials collection in the library } \\
\text { Online materials collection in the library }\end{array}$ & 0.00 & 4.00 & 2.98 & 0.96 \\
\hline & Accessibility of online library throughout the year & 0.00 & 4.00 & 2.86 & 0.96 \\
\hline & Up-to-date ICT resources Up-to-date ICT resources & 0.00 & 4.00 & 2.67 & 0.94 \\
\hline & Assistance for ICT-related challenges & 0.00 & 4.00 & 2.63 & 1.09 \\
\hline & Centre library stocking subject relating materials & 0.00 & 4.00 & 2.44 & 1.02 \\
\hline & Centre library stocking recent research books & 0.00 & 4.00 & 2.40 & 0.98 \\
\hline & Accessibility of computer labs & 0.00 & 4.00 & 2.12 & 1.19 \\
\hline \multicolumn{2}{|c|}{ Grand Total (Infrastructure) } & & & 2.45 & 0.73 \\
\hline \multirow{6}{*}{$\begin{array}{l}\text { ADMINISTRATIVE } \\
\text { SUPPORT }\end{array}$} & User-friendliness of the university/CEES email & 0.00 & 4.00 & 3.06 & 0.91 \\
\hline & Provision of information on doctoral application & 0.00 & 4.00 & 3.12 & 0.87 \\
\hline & Responses on admission decisions & 0.00 & 4.00 & 2.88 & 1.00 \\
\hline & User-friendliness of registration and re-registration & 0.00 & 4.00 & 2.94 & 0.97 \\
\hline & Time span in communicating HDC decisions on proposal & 0.00 & 4.00 & 2.46 & 1.11 \\
\hline & Provision of information on administrative procedures & 0.00 & 4.00 & 2.66 & 0.97 \\
\hline \multicolumn{2}{|c|}{ Grand Total (Administrative Support) } & & & 2.85 & 0.69 \\
\hline \multirow{5}{*}{$\begin{array}{l}\text { ACADEMIC } \\
\text { FACILITATION }\end{array}$} & Doctoral proposal development training & 0.00 & 4.00 & 3.25 & 0.82 \\
\hline & Relevance of training to students' research & 0.00 & 4.00 & 2.84 & 0.96 \\
\hline & Provision of programs for post-proposal students & 0.00 & 4.00 & 2.39 & 1.07 \\
\hline & Training on data analysis soft-wares & 0.00 & 4.00 & 2.46 & 1.02 \\
\hline & Grand Total (Academic Facilitation) & & & 2.74 & 0.75 \\
\hline
\end{tabular}

Table 3 above indicates that the mean values for students' actual experiences on the four dimensions of student support service quality were all below 3.0. For example for each of the dimensions, the grand means were 2.54 (64\%) for supervision support, 2.45 (61\%) for availability of infrastructure, 2.85 (71\%) for administrative support and 2.74 (69\%) for academic facilitation. These results show that the students' actual experiences of the support services at CEES were much lower (less favourable) than their expectations (Table 2), implying that there was generally a high student expectation level $(\mu=3.55)$ and a low level of actual student experiences $(\mu=2.62)$.

\section{Gaps in Student Support Service Quality}

This section observes the research question "Is there a gap (difference) between students' expectations and actual experiences of the quality of postgraduate support services provided?" This is based on the Gap Analysis Theory (Theoretical Framework), which assesses quality by observing the differences between the client's expectations and actual experiences. A dependent t-test was employed, because the data came from one sample, to analyze if there are statistically significant differences of means between the data-in this instance-between expectations and experiences. The analysis was done in such a way that each of the four dimensions (supervision support, infrastructure, administrative support and academic facilitation) was treated separately. Afterwards, comparison of means between the cumulative results of expectations and the cumulative results of experiences was done.

The dimension of supervision support supervision was checked to see if there was a statistically significant difference between the students' expectations and experiences of the support that they got from their supervisors. The matched paired t-test results show that on average, students' actual experiences of supervision support were statistically significantly less $($ Mean $=2.54, \mathrm{SE}=0.061)$ than their expectations $($ Mean $=3.45, \mathrm{SE}=0.038), \mathrm{df}=188 ; \mathrm{t}=13.57$, 
$p<0.001$. This result shows a statistically significant difference at $p$ value of 0.001 , meaning that the students' expectation of the supervision support service quality was higher than their actual experiences (Table 4).

Table 4: t-test Results showing gaps between students' expectations and experiences for each dimension

\begin{tabular}{|c|c|c|c|c|c|c|c|c|c|}
\hline \multirow{3}{*}{ Dimensions } & \multicolumn{6}{|c|}{ Paired Differences } & \multirow{3}{*}{$\mathrm{df}$} & \multirow{3}{*}{$\mathrm{t}$} & \multirow{3}{*}{$\begin{array}{c}\text { p } \leq 0.001 \\
\text { Sig. (2- } \\
\text { tailed) }\end{array}$} \\
\hline & \multicolumn{2}{|c|}{$\begin{array}{c}\text { Actual } \\
\text { Experiences of } \\
\text { Student } \\
\text { Support } \\
\text { Services } \\
\end{array}$} & \multicolumn{2}{|c|}{$\begin{array}{c}\text { Students' } \\
\text { Expectations of } \\
\text { Support } \\
\text { Services }\end{array}$} & \multicolumn{2}{|c|}{$\begin{array}{l}95 \% \text { Confidence } \\
\text { Interval of the } \\
\text { Difference }\end{array}$} & & & \\
\hline & Mean & SE & Mean & SE & Lower & Upper & & & \\
\hline Support Supervision & 2.54 & 0.061 & 3.45 & 0.038 & 0.770 & 1.032 & 148 & 13.57 & .000 \\
\hline $\begin{array}{l}\text { Availability of } \\
\text { Infrastructure }\end{array}$ & 2.45 & 0.052 & 3.47 & 0.044 & 0.894 & 1.132 & 149 & 16.83 & .000 \\
\hline $\begin{array}{l}\text { Administrative } \\
\text { Support }\end{array}$ & 2.85 & 0.047 & 3.56 & 0.036 & 0.597 & 0.798 & 145 & 13.71 & .000 \\
\hline Academic Facilitation & 2.74 & 0.052 & 3.57 & 0.037 & 0.718 & 0.946 & 149 & 14.38 & .000 \\
\hline $\begin{array}{l}\text { Overall difference } \\
(A v . \mu)\end{array}$ & 2.62 & & 3.55 & & & & & & \\
\hline
\end{tabular}

Source: Field data

As shown in Table 4 above, the t-test result for the dimension of infrastructure showed that on average, students' actual experiences of the Infrastructure provided by Makerere University and CEES were statistically less significant (Mean $=2.45, \mathrm{SE}=0.052$ ) than their expectations (Mean $=3.47, \mathrm{SE}=0.044), \mathrm{df}=198 ; \mathrm{t}=16.83, \mathrm{p}<0.001$, implying there is a gap between the students' expectations and actual experiences of student support service quality with regard to the infrastructure that the university and CESS provide.

The result also show that on average, students' actual experiences of administrative support were statistically significantly less (Mean $=2.85, \mathrm{SE}=0.047$ ) than their expectations (Mean = 3.56, $\mathrm{SE}=0.036), \mathrm{df}=214 ; \mathrm{t}=13.71, \mathrm{p}<0.001$, meaning students' expectations still exceed their experiences with regard to the dimension of administrative support.

The fourth dimension that was used to describe the expectations and experiences of students regarding the student support service quality offered by CEES was academic facilitation. The result of the t-test as shown in Table 4 above is that, on average, students' actual experiences of the services under this dimension were statistically less significant (Mean $=2.74, \mathrm{SE}=0.052$ ) than their expectations (Mean $=3.57, \mathrm{SE}=0.037$ ), $\mathrm{df}=207 ; \mathrm{t}=14.38, \mathrm{p}<0.001$. This result shows that there are gaps between students' expectations and experiences; where experiences are lower than expectations.

On the overall difference between expectations and experiences, table 4 above shows that, on average, students' actual experiences of the quality of student support services were statistically less significant (Mean $=2.62, \mathrm{SE}=0.048$ ) than their expectations (Mean $=3.55$, $\mathrm{SE}=0.034), \mathrm{df}=151 ; \mathrm{t}=16.41, \mathrm{p}<0.001$. This result shows that there is a gap between the students' expectations and what they actually experienced on ground regarding the quality of postgraduate support services. This finding further provides evidence that there is overall dissatisfaction by the students to find that their expectations were higher than their actual experiences.

\section{Prediction of the extent to which Quality of Student Support Services influences Students' Satisfaction Levels}

This section of the study deals with the question "To what extent does the quality of postgraduate student support services influence Students' satisfaction levels?" The section deals 
with the relationship between all the four dimensions (supervision support, infrastructure, administrative support, and academic facilitation) used as independent variables and Students' satisfaction as the dependent variable. The statistical tools employed are multiple regression analyses to describe the relationship between the independent variable(s) and the dependent (predicted) variable. With regard to Supervision support and Student satisfaction, Makerere University's postgraduate degree is largely research-based. To make students successful in their postgraduate journey, one of the major support schemes is the allocation of a research supervisor who sees the student through the research process by offering such academic guidance as may be deemed necessary for the accomplishment of a research project.

The ten items that constituted part of this the support supervision dimension measured issues like clarity of supervisor's comments, sharing of useful resources, encouraging and motivating students, and timely responses among others. The regression analysis (Table 5) showed that support supervision was statistically and significantly related with students' satisfaction $(R=0.377)$. And the dimension of supervision support explains $14 \%\left(R^{2}=0.138 ; p<0.001\right)$ of the variation in the dependent variable. However, support supervision and students' satisfaction were inversely (negatively) related ( $\mathrm{t}=-5.54)$, supporting the envisaged gap between students' expectations and their actual experiences as articulated in section 5.3.

Table 5: Multiple Regression Results

\begin{tabular}{llllll}
\hline \multirow{1}{*}{\multicolumn{1}{c}{ Independent Variables }} & \multicolumn{5}{c}{ Dependent Variable: Satisfaction } \\
\cline { 2 - 6 } Support Supervision & Beta & t-value & p-value & R & $\mathbf{R}^{2}$ \\
Infrastructure & -0.091 & -5.544 & 0.001 & 0.377 & 0.138 \\
Administrative support & -0.045 & -1.986 & 0.048 & 0.141 & 0.015 \\
Academic Facilitation & -0.118 & -3.762 & 0.041 & 0.251 & 0.581 \\
\hline
\end{tabular}

Source: Field data

The quantitative findings with regard to infrastructure highlight the following. The dimension of infrastructure consisted of eight items that focused on library and ICT support services like the physical collection and the online resources of the library, the computer laboratories and ICT-related assistance, and the accessibility of the main library ICT facility. The summary of the SPSS results on the dimension of infrastructure showed that this dimension (as shown in Table 5 above) explained only $1.5 \%(\mathrm{R}=0.141)$ of the students' satisfaction level, $\mathrm{R}^{2}=0.015, \mathrm{p}<0.05$. Though this is a very small result, it is statistically significant at $p=0.048$, but infrastructure is negatively (inversely) related with satisfaction $(\mathrm{t}=-1.99)$.

But the quantitative findings with regard to administrative support highlight the following. The six items in the quantitative section of this dimension mainly concentrated on support schemes that were provided in relation to the user-friendliness of the student email account, application procedures, decisions concerning admission, registration, re-registration, information and communication from sections of CEES and Makerere University. The SPSS output that was run to observe its relationship with satisfaction gave the model summary where administrative support explained $6 \%(\mathrm{R}=0.251)$ of the students' satisfaction level, $\mathrm{R}^{2}=0.581, \mathrm{p}<0.05$. Like the dimension of supervision support, the relationship of administrative support with satisfaction was negative $(\mathrm{t}=-3.76)$.

Additionally, the quantitative findings with regard to academic facilitation highlight the following. The four items in the dimension, academic facilitation, focused on the provision of different types of training (postgraduate proposal writing, and the utilization of software packages like SPSS and Atlas-ti). These four items also included an emphasis on the relevance of the training schemes. The summary below shows that this dimension explained $2.6 \%$ 
$(\mathrm{R}=0.175)$ variation to students' satisfaction levels, $\mathrm{R}^{2}=0.026, \mathrm{p}<0.05$. This result, though small, corresponds with the results of the previously discussed dimensions that measured expectation and experience, and the dependent t-test results related to the gap analysis. The direction of the relationship is negative $(\mathrm{t}=-2.54)$. The conclusion that could be drawn from the above analysis is that students enroll for postgraduate education with very high expectations. But in the course of their studies, these expectations are derailed by actual low experiences they encounter on the programs offered.

For the sake of curiosity, the four dimensions that measure students' expectations and experiences were observed through step-wise regression. As shown in Table 6 below, the dimensions of infrastructure and academic facilitation were dropped as having made a less significant contribution as opposed to the other two dimensions (supervision support and administrative support), which explained $19 \%$ of the variance in satisfaction; $\mathrm{R}^{2}=0.190$, $\mathrm{p}<0.001$. This above finding could be interpreted to mean that administrative support and supervision are critical elements in postgraduate education. The survival of academic programming and infrastructure development is highly dependent on the quality of administrative support systems in the university.

Table 6: Step-wise regression of expectation-experience dimension

\begin{tabular}{|c|c|c|c|c|c|c|c|}
\hline \multirow{3}{*}{$\begin{array}{l}\text { Independent } \\
\text { Variables }\end{array}$} & \multicolumn{7}{|c|}{ Dependent Variable: Satisfaction } \\
\hline & \multirow[t]{2}{*}{ Beta } & \multirow[t]{2}{*}{ t-value } & \multirow[t]{2}{*}{ p-value } & \multirow[t]{2}{*}{$\mathbf{R}$} & \multirow[t]{2}{*}{$\mathbf{R}^{2}$} & \multicolumn{2}{|c|}{ Collinearity Statistics } \\
\hline & & & & & & Tolerance & VIF \\
\hline $\begin{array}{l}\text { Supervision } \\
\text { Support }\end{array}$ & -0.081 & -4.342 & 0.001 & 0.448 & 0.190 & 0.831 & 1.203 \\
\hline $\begin{array}{l}\text { Administration } \\
\text { Support }\end{array}$ & -0.079 & -2.087 & 0.039 & & & 0.831 & 1.203 \\
\hline
\end{tabular}

\section{Source: Field Data}

On the other hand, postgraduate education, according to McKenna (2016), is highly determined by the trend and quality of supervision given to students to pursue the conceptual threshold.

\section{DISCUSSION OF RESULTS}

Generally, students highly expected to receive quality support supervision, infrastructure, administrative support, and academic facilitation during their postgraduate education at the College of Education and External Studies, Makerere University. Reasons to support such high student expectations may be partly explained in two arguments. First, the Academy of Science of Southern Africa [ASSAf] (2010) provides that graduates at this level are mooted to be key developers of innovation and development, deemed capable of infusing management logistical systems, diverse critical thinking, able to alter existing conceptual directions and allowing for new possibilities. Second, Cross and Backhouse (2014) as well as Tight (2004) seem to suggest that there is strong Interdisciplinarity uniqueness in postgraduate education because this level offers a glance into a variety of theoretical perspectives strengthening later professional practice. This is why whoever enrolls as a postgraduate student has such high expectations to receive quality mentorship and facilitation to aid him or her in pursuing such positive postgraduate intents.

However, these high student expectations were watered down by contrary experiences whereby the quality of postgraduate support services offered by CEES was really low. The danger in this is that prior possession of high expectations which are then watered down by actual experiences that are poor, might lead to ideological frustrations, loss of hope in higher education, and the eventual withdrawal by the once expectant students and society. According 
to Heen (2002), postgraduate education is ideally supposed to develop knowledge that will address important local socio-economic problems, and produce highly skilled graduates to take leadership positions in their societies is typical to improvement of postgraduate education. Therefore, if the actual experiences of postgraduate education, mentorship and facilitation are poor, then universities might fail to contribute to social development and leadership. The university administration needs to provide postgraduate education support that is equal to student and societal expectations to enable building intellectual cadre-ship, careerism, offer 'locally relevant' and quality educational opportunities.

We predicted the extent to which the quality of student support services influenced their satisfaction levels. The intent was to understand how each of the dimensions contributed to student satisfaction. To begin with, support supervision was expected to significantly explain variations in student satisfaction levels by $14 \%\left(\mathrm{R}^{2}=0.138, \mathrm{p} \leq 0.001\right)$. However in its present form, support supervision at CEES is greatly dissatisfying $(\mathrm{t}=-5.54)$. We conducted follow-up interviews to establish reasons accounting for this statistical observation. Our further findings are that postgraduate supervisors are overwhelmed by the ever increasing student numbers. The academic has many students under his or her supervision on top of having a huge backlog of assignments and research work to attend to. In addition to this overwhelming load, he/she has to participate in research and publication, teaching, school practice and industrial training, conferences and seminars. Academic staff facilitating at postgraduate (Masters' degrees and doctoral levels) further expressed that they are poorly remunerated which does not give them the impetus to give effective supervision support. Because of the poor pay, there is a high academic staff attrition rate whereby many academics at this level are trekking and moonlighting for greener pastures.

Availability of infrastructure explains only $1.5 \%\left(\mathrm{R}^{2}=0.015, \mathrm{p} \leq 0.05\right)$ to student satisfaction levels of the quality of support services, and it is a dissatisfier $(\mathrm{t}=-1.99)$. With the current poor state of infrastructure at CEES denoted by dilapidated buildings, lack of adequate furniture, space problems and a slow and inadequate internet; it is clear that the present infrastructure can hardly enable the College meet postgraduate student expectations. Coupled with a poorly stocked library that lacks new books and information resources, it equally becomes hard for CEES to provide quality research and publication support services at this level. Administrative support also explained only $6 \%\left(\mathrm{R}^{2}=0.581, \mathrm{p} \leq 0.05\right)$ of student satisfaction. In its present form, administrative support is a student dissatisfier $(\mathrm{t}=-3.76)$. We probed for reasons accounting for this poor administrative support status and the following were highlighted from the field notes. First, the college administration has not been in a strong position to provide postgraduate students with relevant and adequate support to facilitate their studies. However, the blame was not wholly put on the leadership of CEES but on the top management that has failed to operationalize its strategic planning intentions especially regarding facilitating and developing the Directorate of Graduate Training of Makerere University.

Finally, academic facilitation explained only $2.6 \%$ to variations in student satisfaction levels, which is statistically $\left(\mathrm{R}^{2}=0.026, \mathrm{p} \leq 0.05\right)$, yet the present academic facilitation is not any satisfying to students $(\mathrm{t}=-2.54)$. Student research trainings, seminars and workshop experiences are rarely conducted to reinforce their proposal writing and data analysis skills.

\section{CONCLUSION AND WAY FORWARD}

It can be argued that the quality of postgraduate support services at CEES is generally low because of the profound lack of support supervision, poor and inadequate infrastructure, lack of administrative support, and inadequate academic facilitation. In this sensibility, the solution to the above challenge rests in John Stuart Mill's Utilitarian Theory partly to provide 
theoretical insights to counter this aberration. From a moral philosophy standpoint, the quality of service delivery at an institutional level is a utility maximizing requisite. Maximizing quality in postgraduate education is a utility problem with distinct philosophical bounds, and these exist partly in John Stuart Mill's Utility supposition. Mill's Utilitarian theory generally holds that the morally right action, is where one ought to maximize the overall good- "Summum Bonum" (Donner, 2011), whereby the overall good is actually satisfying the quality test (Clewes, 2003; Cronin \& Taylor, 1992). What is distinctive about utilitarianism is "its approach to taking...an account of moral evaluation and moral direction that expands on it" (Donner, 1991; Driver, 2004:181).

For example, Quality Service Support in Postgraduate Education must provide moral direction that increases happiness (or satisfaction) to students, which is the utilitarian philosophical recounting of virtuousness (Hruschka, 1991). To the "Theological Utilitarians", quality service provision is equated to promoting human happiness as the Devine point of departure (Gill, 2006; Long, 1990). Therefore to Mills, Utility is a "hedonic sophistry" influenced by perfectionist intuitions such as pursuit for quality service (Rosen, 2003) in "intellectual pleasures" (Hruschka, 1991:168). Interpreted in the context of the study bounds, this seems to mean that postgraduate education pursuit - as an intellectual pleasure-is a higher level value that should be pursued with satisfaction to those consummating it (students) and should be preserved through establishing strong support systems to safeguard its credibility (Boote \& Beile, 2005).

In order to pursue John Stuart Mill's Utilitarian Principles in postgraduate service support, we recommend the following expectations:

a) There is need for university bureaucrats to strengthen the administrative arm of postgraduate training at Makerere University at a policy level and also strengthen postgraduate supervision at a micro-level because these supports are critical elements to the survival of postgraduate education. This can be achieved through designing a robust postgraduate strategic planning framework that should earnestly address the 4dimensions of student support-supervision, administration, infrastructure, and academic facilitation.

b) Strengthen postgraduate support by improving academic staff remuneration in order to retain expertise. This could be achieved through enhanced budget allocations in this direction as well as provision of incentives such as "sabbatical leaves" for high caliber staff, promotion of academic staff and payment of attractive supervision allowances so as to put CEES and Makerere to world rankings.

c) Retaining aging professors at the status of "professor emeritus" with the duty to mentor young academics and also assist in supervision to tackle the soaring student numbers and reduce backlog, as well as facilitating research training for both postgraduate academic and students.

d) Invest in postgraduate infrastructure development. There is need to set up "centres of excellence" to be utilized by postgraduate students and academic staff. For example, there is need for a modern library facility for the College of Education and External Studies (CEES) with ICT facility and "postgraduate commons" where serious intellectual work can be accommodated.

e) The College of Education and External Studies should also provide postdoctoral chairs to both national and international academics in order to attract a multiplicity of expertise mainly for development of postgraduate training. This could be done by i) establishing a research fund at the college and at the Directorate of Graduate Training, ii) designing research agendas/strands for each faculty and department and then invite applications from prospective fellows. 
f) Encourage postgraduate communities for the smooth running of student research supervision and support. These postgraduate communities will facilitate 'mobile scholarship' with students and academic staff from culturally and scientifically diverse backgrounds becoming more likely to hasten intellectual mobility (Connell, 2007), and encounter multiple intercultural experiences that define diverse postgraduate research supervision leaderships (Cadman \& Ha, 2001).

This study had some limitations and ethical considerations. Although the study was conducted on both Masters' and Doctoral students, the number of Doctoral students was small because mainly their size is naturally smaller than that of the Masters students. This reality somehow has an impact of the research outputs. The study was focused only on the College of Education and External Studies (CEES) of Makerere University which makes the generalization of results to the entire university and to other postgraduate offering universities in Uganda, hard. The same study had some ethical issues. Because the subject of service quality is a delicate institutional function, researching on the quality of an institution's undertakings is always a political snag. We managed to effectively and efficiently conduct research on this subject by committing our clients that their names shall remain confidential and that participation in the study was a voluntary affair, and whoever wanted to leave would do so at will.

\section{References}

Academy of Science of South Africa [ASSAf] (2010). The PhD study: An evidence-based study on how to meet the demands for high-level skills in an emerging economy. Pretoria: Academy of Science of South Africa.

Backhouse, J. (2009). Doctoral Education in South Africa: Models, Pedagogies, and Student Experiences. PhD Thesis, Department of Education, University of the Witwatersrand.

Barnes, B.R. (2007). Analyzing service quality: The case of post-graduate Chinese students. Total Quality Management, 18(3), 313-331.

Bolliger, D.U., \& Halupa, C. (2012). Student perceptions of satisfaction and anxiety in an online doctoral program, Distance Education, 33(1), 81-98, DOI: 10.1080/01587919.2012.667961.

Boote, D.N., \& Beile, P. (2005). Scholars before researchers: On the centrality of the dissertation literature review in research preparation. Educational Researcher, Vol. 34 (6), 3-15.

Cadman, K., \& Ha, H. T. (2001). 'Only connect': Transcultural supervision as the 'Rainbow Bridge'. In A. Bartlett \& G. Mercer (Eds.), Postgraduate research supervision: Transforming (r)elations(pp. 215-232). New York: Peter Lang.

Clewes, D. (2003). A student-centered conceptual model of service quality in higher education. Quality in Higher Education, 9(1), 69-85.

Commonwealth Department of Science and Training (2002). Higher Education at the Cross roads: An overview paper. Canberra: DEST.

Connell, R. (2007). Southern Theory. Crows-Nest, NSW: Allen \& Unwin.

Creswell, J.W. (2009). Research design: Qualitative, quantitative and mixed methods approaches. ( $3^{\text {rd }}$ Ed.). London: Sage.

Cronin, J.J., \& Taylor, S.A. (1992). Measuring service quality: A reexamination and extension. Journal of Marketing, 56(3), pp.55-68.

Dann, S. (2008). Applying services marketing principles to postgraduate supervision. Quality Assurance in Education, 16(4), 333-346.

Donner, W. (1991). The Liberal Self: John Stuart Mill's Moral and Political Philosophy, Ithaca, NY: Cornell University Press.

Donner, W. (2011). “Morality, Virtue, and Aesthetics in Mill's Art of Life,” in Ben Eggleston, Dale E. Miller, \& David Weinstein (eds.) John Stuart Mill and the Art of Life, Oxford: Oxford University Press.

Driver, Julia, (2004). Pleasure as the Standard of Virtue in Hume's Moral Philosophy. Pacific Philosophical Quarterly, 85, 173-194. 
Evans, A.J., Brian, M., and Oladeji, K. (2011). Impact of organizational resources on quality of services in distance and open learning in Botswana. Indian Journal of Open Learning, 20(3), 163-178.

Firadus A. (2005). HEdPERF versus SERVPERF: The quest for ideal measuring instrument of service quality in higher education sector, Quality Assurance in Education, 13(4), 305-328.

Gill, M. (2006). The British Moralists on Human Nature and the Birth of Secular Ethics, New York, NY: Cambridge University Press.

Government White Paper (1993). Government of Uganda. Ministry of Education and Sports. Kampala Uganda.

Harvey, L., \& Green, D. (1993). Defining quality. Assessment and Evaluation in Higher Education, 18(1), 9-34.

Hasan, M., \& Kerr, R.M. (2003). The relationship between total quality management practices and organizational performance in service organizations. The TQM Magazine, 15(4), 286-291.

Heen, E.F. (2002). Research priorities and disciplinary cultures. Friends or Foes? A Cross-national Study on doctoral research training in economics in France and Norway. Higher Education Policy, Vol. 15(1), 77-95.

Hill, F.M. (1995). Managing service quality in higher education: The role of the student as primary customer. Quality Assurance in Education, 3(3), 10-21.

Hruschka, J. (1991). The Greatest Happiness Principle and Other Early German Anticipations of Utilitarian Theory, Utilitas, 3, 165-77.

Jancey, J., \& Burns, S. (2013). Institutional factors and the postgraduate student experience. Quality Assurance in Education, 21(3), 311-322.

Jayasundara, C.C. (2009). Developing a model for predicting customer satisfaction in relation to service quality in university libraries in Sri-Lanka. Unpublished Doctoral Thesis. University of South Africa, Pretoria.

Joseph, M., Yakhou, M., \& Stone, G. (2005). An educational institution's quest for service quality: customers' perspective. Quality Assurance in Education, 13(1), 66-82.

Jung, I., Wong, T.M. Li, C., Baigaltugs, S., \& Belawati, T. (2011). Quality assurance in Asian distance education: Diverse approaches and common culture. International Review of Research in Open and Distance Learning (IRRODL), 12(6), 63-83.

Juran, J.M. (1999). How to think about quality. In J.M. Juran and A.B. Godfrey (Eds.), Juran's Quality Handbook (pp. 2.1-2.17). New York: McGraw-Hill.

Kasozi, A.B.K. (2002). Financing Uganda's University Education: Challenges and Remedies. Kampala. Fountain Publishers.

Kiley, M., \&Wisker, G. (2009).Threshold concepts in research education and evidence of threshold crossing. Higher Education Research \& Development, 28, 431-441.

Kitchroen, K. (2004). Literature review: Service quality in educational institutions. ABAC Journal, 24(2), 14-25.

Kuo, Y.F., Wu, C.M., \& Deng, W.J. (2009). The relationship among service quality, perceived value, customer satisfaction, and post-purchase intention in mobile value-added services. Computers in Human Behavior, 25, 887896.

Lampley, J.H. (2001). Service quality in higher education: Expectations versus experiences of doctoral students. Journal of the American Association of Collegiate Registrars and Admissions Officers, 77(2), 9-14.

Li, R.Y., \& Kaye, M. (1999). Measuring service quality in the context of teaching: A study on the longitudinal nature of students' expectations and perceptions. Innovations in Education and Training International, 36(2), 145-154.

Long, D. (1990). 'Utility' and the 'Utility Principle': Hume, Smith, Bentham, Mill.” Utilitas, 2, 12-39.

Lovelock, C., \& Gummesson, E. (2004). Whither service marketing? In search of a new paradigm and fresh perspective. Journal of Service Research, 7(1), 20-41.

Malhotra, N.K., Ulgado, F.M., Agarwal, J., Shainesh, G., \& Wu, L. (2005). Dimensions of service quality in developed and developing economies: Multi-country Cross-cultural comparisons. International Marketing Review, 22(3), 256-278.

McAlpine, L., \& Norton, J. (2006). Reframing our approach to Doctoral programmes: An integrative framework for action and research. Higher education Research \& Development, Vol. 25 (1), pp.3-17.

Mhalanga, E. (2010). Theoretical perspectives. In L. Cameron (Ed.), Quality assurance toolkit for open schools (228). Vancouver: Commonwealth of Learning. 
Mugagga, A. (2010). Philosophical Implications of the Liberalization of University Education in Uganda. Unpublished Doctoral Dissertation. Makerere University. Uganda.

Mulu Nega. (2012). Quality and quality assurance in Ethiopian higher education: Critical issues and practical implications. Unpublished Doctoral Thesis. University of Twente, Twente.

Muyingo, J.C. (2004). Changing Patterns in Financing of University Education in Uganda and its Implications in Management of Universities. Unpublished Doctoral Thesis. Makerere University. Kampala.

Mwenje, S., \& Saruchera, K. (2013). Assessing student support service quality in Open Distance Learning (ODL): A learner perspective at Zimbabwe Open University (ZOU) - Manica-land Region, Global Advanced Research. Journal of Educational Research and Review, 2(6), 131-138.

National Council for Higher Education (NCHE) Quality Assurance Policy Framework (2012). NCHE head quarters. Kampala.

Ndudzo, D. (2014). An analysis of the perceptions and expectations of students towards the quality of service delivery in open and distance learning: a case of the Zimbabwe Open University. Unpublished Doctoral Thesis. Zimbabwe Open University, Harare.

Nsubuga, Y. (2008). Impact of Leadership Styles in Management of Academic Performance in Science Subjects in Secondary Schools in Uganda. Unpublished Doctoral Thesis. Nelson Mandela Metropolitan University, Kampala.

Nyenya, T., \& Bukaliya, R. (2015). Comparing students' expectations with the students' perceptions of service quality provided in open and distance learning institutions in Zimbabwe's Mashonaland east region. International Journal of Research in Humanities and Social Studies, 2(4), 45-53.

Ogunleye, A. (2013). Quality assurance and quality indicators in open and distance education: Context, concerns and challenges. International Journal of Educational Research and Technology, 4(2), 49-62.

Ong, W.M., \& Nankervis, A. (2012). Service quality in higher education: Students' perceptions in Australia and Malaysia. Review of Integrative Business and Economics Research, 1(1), 277-298.

Parasuraman, A., Zeithaml, V.A., \& Berry, L.L. (1985). A conceptual model of service quality and its implications for future research. Journal of Marketing, 49(4), 41-50.

Parasuraman, A., Zeithaml, V.A., \& Berry, L.L. (1988). SERVQUAL: A multiple-item scale for measuring consumer perceptions of service quality. Journal of Retailing, 64(1), 12-40.

Parasuraman, A., Zeithaml, V.A., \& Berry, L.L. (1994). Reassessment of expectations as a comparison standard in measuring service quality: Implications for further research. Journal of Marketing, 58(1), 111-124.

Pereda, M., Airey, D., \& Bennett, M. (2007). Service quality in higher education: The experience of overseas students. Journal of Hospitality, Leisure, Sport \& Tourism Education, 6(2), 55-67.

Pereda, M.H. (2006). An examination of the impact of service quality dimensions on students' satisfaction in higher education in the UK. Unpublished Doctoral Thesis. University of Surrey, Surrey.

Rosen, F. (2003). Reading Hume Backwards: Utility as the Foundation of Morals. In Frederick Rosen (ed.), Classical Utilitarianism from Hume to Mill, London: Routledge, 29-57.

Rwendeire, A. (2012). The Big Dream: A Glimpse at Uganda's Future. Highlights of Vision 2040. Keynote Address at the Celebration of Uganda's Golden Jubilee. Vienna.

Ryan, Alan, (1990). The Philosophy of John Stuart Mill, Amherst, NY: Prometheus Books.

Sandmaung, M., and Khang, D.B. (2013). Quality expectations in Thai higher education institutions: multiple stakeholder perspectives. Quality Assurance in Education, 21(3), 260-281.

Sawyer, A. (2004). Challenges facing African Universities. African Studies Review, Vol. 47(1), pp.1-59.

Schofield, P. (2006). Utility and Democracy: the Political Thought of Jeremy Bentham, Oxford: Oxford University Press.

Shaik, N., Lowe, S., \& Pinegar, K., (2006) DL-sQUAL: A multiple-item scale for measuring service quality of online distance learning programs. Online Journal of Distance Learning Administration, 9(2).

Sioux McKenna (2016): Crossing conceptual thresholds in doctoral communities, Innovations in Education and Teaching International, DOI:10.1080/14703297.2016.1155471

Smith, J.A., \& Osborne, M. (2003). Interpretative Phenomenological Analysis. In J.A. Smith (Ed.), Qualitative Psychology: A Practical Guide to Research Methods (pp.51-80). London: Sage Publications. 
Ssekamwa, J.C. (2002). History and Development of Education in Uganda. Kampala. Fountain Publishers.

Sultan, P., \& Wong, H.Y. (2010). Service quality in higher education - A review and research agenda. International Journal of Quality and Service Sciences, 2(2), 259-272.

Sultan, P., and Wong, H.Y. (2013). Antecedents and consequences of service quality in a higher education context: A qualitative research approach. Quality Assurance in Education, 21(1), 70-95.

Svanton, D.L. \& Manyika, S. (2002). PhD programmes in African Universities: Current status and future prospects. Berkeley: The institute of international studies and centre for African Studies, University of California, Berkeley.

Talib, F., Rahman, Z., \& Qureshi, M.N. (2013). An empirical investigation of relationship between total quality management practices and quality performance in Indian service companies. International Journal of Quality and Reliability Management, 30(3), 280-318.

Tan, K.C., and Kek, S.W. (2004). Service quality in higher education using an enhanced SERVQUAL approach. Quality in Higher Education, 10(1), 17-24.

Teeroovengadum, V., Kamalanabhan, T.J., \& Seebaluck, A.K. (2016). Measuring service quality in higher education. Quality Assurance in Education, 24(2), 244-258.

Tight, M. (2004) 'Research into higher education: a-theoretical community of practice' Higher Education Research and Development, 24(4) pp.395-411.

Trafford, V., \& Leshem, S. (2009). Doctorateness as a threshold concept. Innovations in Education and Teaching International, 46, 305-316.

Truett, M \& Truett, A. (1990). Microeconomics. Portland State University. USA.

Vanstone, M., Hibbert, K., Kinsella, E. A., McKenzie, P., Pitman, A., \& Lingard, L. (2013). Interdisciplinary doctoral research supervision: A scoping review. Canadian Journal of Higher Education, Vol. 43 (2): pps.42-67

Watson, S. (2003). Closing the feedback loop: Ensuring effective action from student feedback. Tertiary Education and Management, 9(2), 145-157.

Yener, D. (2013). Students' perceived service quality of distance learning courses in a dual-mode education system. Contemporary Educational Technology, 4(1), 50-65.

Yeo, R.K. (2009). Service quality ideals in a competitive tertiary environment. International Journal of Educational Research, 48(1), 62-76.

Yeo. R.K., \& Li, J. (2014). Beyond SERVQUAL: The competitive forces of higher education in Singapore. Total Quality Management and Business Excellence, 25(1/2), 95-123

Zeithaml, V.A., Berry, L.L., \& Parasuraman, A. (1996). The behavioral consequences of service quality. Journal of Marketing, 60, 31-46. 


\section{APPENDIX 1 \\ QUESTIONNAIRE}

This instrument was answered in two modes. In the first mode, students' expectations were evaluated on the given instrument items. In the second mode, students' actual experiences were assessed using the instrument items below.

\section{Response Rating: $\quad$ 1=Strongly Disagree; 2= Disagree; 3=I do not know; 4=Agree;} $5=$ Strongly Agree

\begin{tabular}{|c|c|c|c|c|c|}
\hline \multirow{2}{*}{\multicolumn{6}{|c|}{$\begin{array}{l}\text { SUPERVISION SUPPORT } \\
\text { Supervisors give clear comments on students' submissions like } \\
\text { proposals or chapters }\end{array}$}} \\
\hline & & & & & \\
\hline \multicolumn{6}{|l|}{$\begin{array}{l}\text { Supervisors acknowledge the receipt of their students' submissions } \\
\text { without delay }\end{array}$} \\
\hline \multicolumn{6}{|l|}{$\begin{array}{l}\text { Supervisors give adequate information to their students on ethical } \\
\text { clearance procedures }\end{array}$} \\
\hline \multicolumn{6}{|l|}{$\begin{array}{l}\text { Supervisors reflect an approachable attitude when communicating } \\
\text { with their students }\end{array}$} \\
\hline \multicolumn{6}{|l|}{$\begin{array}{l}\text { Supervisors alert students of useful resources related to the } \\
\text { students' research and academic projects }\end{array}$} \\
\hline \multicolumn{6}{|l|}{$\begin{array}{l}\text { Supervisors communicate with their students via different } \\
\text { technological media }\end{array}$} \\
\hline \multicolumn{6}{|l|}{$\begin{array}{l}\text { Supervisors give guidance to their students regarding policies and } \\
\text { rules (like plagiarism or structural requirements of the thesis) that } \\
\text { govern postgraduate studies }\end{array}$} \\
\hline \multicolumn{6}{|l|}{$\begin{array}{l}\text { Supervisors respond to their students' enquiries and submissions } \\
\text { within a reasonable period of time }\end{array}$} \\
\hline \multicolumn{6}{|l|}{$\begin{array}{l}\text { Supervisors encourage their students to complete and submit draft } \\
\text { chapters on a regular basis }\end{array}$} \\
\hline \multicolumn{6}{|l|}{$\begin{array}{l}\text { Supervisors are fairly consistent over time in the comments they give } \\
\text { to their students (not reversing ideas on what they have suggested } \\
\text { before) }\end{array}$} \\
\hline INFRASTRUCTURE & 1 & 2 & 3 & 4 & 5 \\
\hline \multicolumn{6}{|l|}{$\begin{array}{l}\text { Makerere University/CEES Library is rich in e-journal and e-book } \\
\text { collections }\end{array}$} \\
\hline \multicolumn{6}{|l|}{$\begin{array}{l}\text { Makerere University/CEES has a web-based Learning Management } \\
\text { System to encourage students' inter-disciplinarity by providing a } \\
\text { dedicated discussion forum for postgraduate students }\end{array}$} \\
\hline \multicolumn{6}{|l|}{$\begin{array}{l}\text { The University Library Commons are accessible to postgraduate } \\
\text { students after normal working hours }\end{array}$} \\
\hline \multicolumn{6}{|l|}{$\begin{array}{l}\text { Makerere University/CEES ensures that the online Library is } \\
\text { accessible } 24 / 7 \text { throughout the year }\end{array}$} \\
\hline \multicolumn{6}{|l|}{$\begin{array}{l}\text { The College of Education and External Studies (CEES) makes sure } \\
\text { venues available for postgraduate workshops/seminars/training } \\
\text { that are easily accessible to students }\end{array}$} \\
\hline \multicolumn{6}{|l|}{$\begin{array}{l}\text { The University Library/CEES keeps ICT resources in the computer } \\
\text { labs and Library up-to-date }\end{array}$} \\
\hline \multicolumn{6}{|l|}{$\begin{array}{l}\text { Makerere University/CEES ensures that the web-based Learning } \\
\text { Management System is user-friendly }\end{array}$} \\
\hline $\begin{array}{l}\text { Makerere University/CEES makes the e-mail account it provides to } \\
\text { its students user-friendly }\end{array}$ & & & & & \\
\hline
\end{tabular}


Makerere University/CEES makes technical assistance readily available when students face ICT-related problems

Makerere University/CEES ensures that its Library possesses a wide range of subject-related and research books

Makerere University/CEES makes computer labs accessible to students

Makerere University/CEES has facilities in a reachable location so that students can access available services in person

\section{ADMINISTRATIVE SUPPORT}

Makerere University/CEES provides full information on the admission requirements for postgraduate study (e.g. admission criteria, cost, mode of education, and potential fields of study) before students apply

Makerere University/CEES provides information on postgraduate applications in both hard copy and digital (online) format Makerere University/CEES registrar gives response over admission decisions of first application within reasonable period of time Makerere University/CEES ensures that the administrative processes of registration and re-registration are user-friendly Makerere University/CEES ensures that self-sponsored students' payment processes are finalized timeously.

ACADEMIC FACILITATION

Makerere University/CEES provides orientation programs to newly admitted postgraduate students to help them get acquainted with the nature of higher education learning

The orientation program that is given by Makerere University/CEEC academic staff is early enough in the new academic year Makerere University/CEES assigns mentors to postgraduate students who have local supervisors

Makerere University/CEES assigns supervisors or contact persons upon first registration

Makerere University/CEES provides training to students on how to develop a postgraduate academic proposal

Makerere University/CEES has staff members who actively encourage and support postgraduate students

Makerere University/CEES provides training on how to access and download sources from the library

Makerere University/CEES delivers hard copy books that are borrowed from the main Library and College Library to personal addresses of students

Makerere University/CEES assigns subject librarians to the task of providing assistance in finding relevant sources

Makerere University/CEES addresses issues in the postgraduate workshops/seminars/ training that are relevant to the various projects students are involved in Makerere University/CEES makes sure that supervisors and students sign supervision agreements and codes of conduct as early as the assignment of the supervisor

Makerere University/CEES provides training on data analysis software packages (like SPSS and Atlas-ti) 


\begin{tabular}{|c|c|c|c|c|c|}
\hline $\begin{array}{l}\text { Makerere University/CEES provides training programs in the form of } \\
\text { seminars/colloquia beyond the proposal phase }\end{array}$ & & & & & \\
\hline STUDENT SATISFACTION & 1 & 2 & 3 & 4 & 5 \\
\hline $\begin{array}{l}\text { Overall, I am satisfied with the postgraduate services rendered by } \\
\text { the College of Education and External Studies/Makerere University }\end{array}$ & & & & & \\
\hline $\begin{array}{l}\text { I recommend postgraduate study to friends/relatives/family } \\
\text { members because all my study expectations are met }\end{array}$ & & & & & \\
\hline
\end{tabular}

